\title{
Neurodiversity as Status Group, and as a Class-within-a-Class: Critical Realism and Dyslexia*
}

\author{
Chris Adam-Bagley \\ University of Southampton, Southampton, UK \\ Email: christopher.adam@outlook.com
}

How to cite this paper: Adam-Bagley, C. (2022). Neurodiversity as Status Group, and as a Class-within-a-Class: Critical Realism and Dyslexia. Open Journal of Social Sciences, 10, 117-129.

https://doi.org/10.4236/jss.2022.101009

Received: November 23, 2021

Accepted: January 11, 2022

Published: January 14, 2022

Copyright (อ 2022 by author(s) and Scientific Research Publishing Inc. This work is licensed under the Creative Commons Attribution International License (CC BY 4.0).

http://creativecommons.org/licenses/by/4.0/

\section{(c) (i) Open Access}

\begin{abstract}
Dyslexia is seen as one of a number of often overlapping neurodiversities which define a disadvantaged sector of the general population in developed countries. Neurodiversity is redefined in terms of the positive advantages of being a member of this "status group". The role and status of this group in society are considered in the light of stratification theorists such as Marx and Bhaskar-with advocacy for group consciousness as a "class within a class" (Marx) in seeking and asserting change, using Bhaskar's critical realist model. The paper draws on the work of recent scholars and political activists in advocating a model of "humanist class struggle" by the neurodiverse community, adopting Janine Booth's model of trade union enterprise on behalf of the neurodiverse class of workers.
\end{abstract}

\section{Keywords}

Dyslexia Neurodiversity, Social Class, Rentier Class, Marxism, United Kingdom

\section{Introduction: Defining Neurodiversity}

Although the Conference for which this paper was prepared focussed on dyslexia, I want to place $d y$ slexia (a negative word, in which $d y s$ implies abnormality and dysfunction ${ }^{1}$ ) within a broader context of meaning. First, individuals with a particular style of information processing which is not shared by the majority of society, are not abnormal, just as people whose atypical sexual orientation, ethnicity, religion, gender, intellectual level, occupational choice, relationship style *Based on a paper given to the UK Dyslexia Institute Online Conference "Rebel Voices, 2021", September 2021.

${ }^{1}$ dys- in American English is "bad, ill, abnormal, impaired, difficult, etc." e.g. dysfunction. Webster's New World College Dictionary, 4th Edition. 
(e.g. Asperger's), or brain processing (e.g. people with epilepsy) are not abnormal. The complex intersection of statuses (Adam-Bagley \& Abubaker, 2019) makes our personal adaptations and achievements challenging to describe, to the extent that we can all tell our unique, individual stories in the expectation that in this mutual exchange of individuality and values, and we form what Margaret Archer (2003) calls a "morphogenic culture", in which individuals exchange ideas in a dialectic process of "critical realism" which shines a light on the many pathways towards social change and development.

People with dyslexia are part of the neurodiverse community, in which the negativity of the dyslexia label may be trumped by adopting a negative term with pride, just as gay people have proudly adopted the term "queer". For example, Britain's counter-espionage agency GCHQ was actively recruiting "neurodiverse dyslexics" (Hall, 2021), since it has been recognised that such individuals who (like the gay/dyslexic/Asperger's Alan Turing) are particularly likely to explore complexities in the visual and symbolic environment which are crucial in code-breaking and other tasks.

Janine Booth (Booth, 2016, 2018, 2021) begins her writing as a gay person with Asperger's, giving a socialist account (based on trade union activity) of a social structure which seeks to establish and ethical social contract, grounded in the Marxist dictum "from each according to their ability, to each according to their means", between all of the diverse social, cultural, value-based and ability-oriented groups which will co-operate in post-capitalist cultures.

Booth observes that: "Since autistic activist Judy Singer coined the term 'neurodiversity' some twenty years ago, it has facilitated great enlightenment and a progressive new approach to the experiences and rights of autistic and other neurologically atypical people. It is now facing a backlash, much of which is reactionary but some of which has been helped by flaws in some presentations of neurodiversity... an effective neurodiversity approach is one that locates neurodiversity in social structures. (At first)... the neurodiversity approach enabled us to supersede a highly pathological and disabling view of autistic and other neurodivergent people into a far more empowering one."

In particular, according to Booth, the pioneering work of Silberman (2017) and others on neurodiversity enables us to identify that humanity is naturally neurologically diverse and that differently-structured brains are not "faulty" and deviant. There are good reasons why these conditions have remained in the human gene pool. We can now, with good conscience and with vigour "...progress from 'awareness' to 'acceptance', and thus from pity to demands for rights and equality" focussing on how social structures and environments disable people who are neurologically atypical, in the fight for social change in preference to "cures", in which apparently pathological brains can be changed through (for example) the "chemical castration" of Alan Turing, the recent resurgence in "conversion therapies", and the many pseudo-medical approaches which demean neurodiverse people, including those who process informational cues, en- 
vironmental and social signals, and sexuality in ways which do not please a conservative majority.

But according to Booth, although the neurodiversity approach has won wide support, it has certainly not become a generally accepted ideology or model of how social structures should regard and integrate "minority" groups. The older, pathological view still dominates our social structures and political decision-making. Even where public authorities and employers adopt the language of neurodiversity, they usually do not apply it in practice: they pathologize, discriminate against and mistreat neurodivergent people. Acceptance of neurodiversity remains a minority, radical approach, but one that offers the hope of a liberating social transformation.

Booth wishes to advance beyond "simple neurodiversity", focussing now on specific approaches for empowering all individuals who remain disempowered and oppressed in social structures based on the hegemonic values of maintaining the wealth, power and status of a ruling class. The different "disabling statuses" within a disabling social structure (e.g. autism, Asperger's, dyslexia, ADDH, epilepsy, gender and gender variations, ethnicity, religion, the precariat, the chavs, etc) intersect, generating sub-systems of values and oppressions ${ }^{2}$.

She uses a Marxist analysis to arrive at the view that: “...When we look at how employers exclude neurodivergent workers, we are considering a specific social relationship in which 'employers' and 'workers' are different categories of people with different relationships to production. When we look at parenting of neurodivergent kids, we are considering the way in which parenting is structured as a private activity... And when we look at so-called disability, we are considering how our physical, sensory and social environment, and features of our own selves in conjunction with that environment, might create difficulties for us. Understanding our experience in these terms is known as a materialist approach... A materialist understanding of neurodiversity, rather than one based on pathology or identity, will enable us to better understand the oppression of neurodivergent people. It will also enable us to imagine and fight for the reorganisation of society that will embrace and support neurodivergent and neurotypical people."

\section{Neurodiversity: A Social Class Analysis}

Any analysis of social stratification must begin with a consideration of the work of Karl Marx, and how his original ideas have been interpreted, practised and modified over the years, into ideas and analyses which are still relevant today. Marx argued that human values and consciousness were rooted in how individuals were linked to systems of property owning, production, trade, and labour. Those who benefited economically from a capitalist system engineered a social order which controlled the mass of the workers, though a system of "false

${ }^{2}$ For a description and analysis of the underclass groups variously called chavs, and the precariat see (Sawyerr \& Adam-Bagley, 2017a), Chapter 2. 
consciousness" in which exploited workers failed to unite in ways which could emancipate them from this alienation, this separation of consciousness from the social energy which was generated by workers employed on similar tasks. Trade Unions have attempted to both liberate workers from this false consciousness, and to introduce social reforms which have curbed the worst excesses of human exploitation on which capitalism has thrived.

Marx's writing on class, and status groups within class strata are complex and challenging, and are still being interpreted and reformulated today (Hurst, 2007; Bannerji, 2005; Banfield, 2015; Zizek et al., 2018; Christophers, 2018, 2019a, 2019b, 2020, 2021; Hamsa, 2018; Harvey, 2017; Zizek et al., 2018; Milner, 2019; Adler, 2019). It is clear that, despite the failures of Marxist-Leninist applications, the class analyses of Marx are still highly relevant for understanding and changing how a capitalist-dominated social system dominates and disadvantages class groups, in particular those whom we call the neurodiverse strata (Silberman, 2017). We include amongst the neurodiverse those individuals who process social and cognitive information in "mainstream" ways, but nevertheless are categorised because of their social origins, to become members of the precariat (to use Standing $(2010,2012,2014,2021)$ adaptation of Marx's term the proletariat). The precariat is a mass of workers with fewer educational achievements and little vocational training, who occupy minimum-wage jobs on precarious contracts. In times of economic stress they are easily laid off, to become "the reserve army of labour" who can be called upon to work as and when a capitalist system needs them (see Table 2 appended). And beneath them are the class whom both Marx and Standing call "the lumpenproletariat", the strata whom we, the general masses, can ritually abuse as a neurodiverse class who fail in school, and who are destined for marginal lives of petty crime and imprisonment.

Hamsa (2018) includes Karl Marx among the distinguished company of those with dyslexia (a term he uses metaphorically, rather than clinically). Capitalism, now in its "neoliberal phase" is changing shape, with fresh structures and ideologies to deceive the world's community of workers, in its movement towards being a hidden economy, with its wealth housed offshore in its new "rentier" phase, described by Standing (2021) in his book The Corruption of Capitalism: Why Rentiers Thrive and Work Does Not Pay. Here Standing argues that capitalism has entered its most powerful phase (beginning, Hamza and Christophers argue, in about 1980), with the consolidation of the rentier class, who own but do not manage the business of industry (that is the work of a managerial class of lackeys, who administer a precariat system-Standing (2010, 2012, 2014, 2021). This managerial class is like the overseers of slave plantations, who create wealth for offshore elite. Christophers (2019a, 2019b) details the nature of rentierism in the UK, identifying eight-core asset types which are detailed in Table 1 appended.

Much of Standing's seminal work has been generated in Third World economies, and is elaborated in his influential analyses of the delivery and benefits of a 
basic income for all citizens. Most of the immense wealth of the rentier class is housed in havens which escape conventional tax systems (Dünhaupt, 2012; Drucker \& Hakins, 2021; Ford, 2020). The ways in which rentiers, the manipulators of neoliberalism's international income move profits between countries and banks in ways which avoid tax and accrue vast fortunes, is detailed by Shaxson (2018). Rentiers hardly form a secret cabal: rather, capitalistic economies acquiesce in this tax avoidance for a relatively small share of the trillions amassed by rentiers. The price that ordinary citizens pay is the increased underfunding of education, social services, and health care (Sawyerr \& Adam-Bagley, $2017 b)$. The decline in the proportions of national wealth assigned to education and learning services since 2010 is paralleled by the rise in wealth of the richest two percent of the nation, those who exploit British workers for their own wealth creation-between 2014 and 2018 their residual wealth increased by more than $£ 400$ billion, on which they paid tax at the rate of about $3 \%$. Even this payment of tax was little more than a publicity gesture, given the numerous ways in which the movement of profits offshore, avoids tax (Holpuch, 2021). Collins et al. (2021) refer to the huge increase in the income of the world's wealthiest two percent since the ascendancy of neoliberalism since 1979 as "a new feudalism", in a world in which some 100 "dynastic families" have seen their wealth increase by an average of $1000 \%$ in the 50 years since 1980 . Collins et al. argue that with such great wealth comes great political power (including the ability to arrange tax regimes), and the disciplining of the poor through insecure contracts, especially for the stigmatised group of the "neurodiverse", the new serfs in capitalism's latest victorious phase. Even the managerial lackeys, the new overseer class, serve the political goal of the rentier class, as Christophers (2018, 2019a, 2019b, 2020, 2021), Collins et al. (2021) and Drucker \& Hakins (2021) demonstrate.

The most excoriating critic of the stranglehold which capitalism has upon workers' welfare (including the subordination of a neurodiverse underclass) is Christian Marazzi (2010a, 2010b, 2011) who describes rentier capitalism as a silent plague, which has exploited the worst traits in human relationships, profiting from turning ethnic, religious and ideological groups against one another in forms of prejudice and pseudo-warfare which reinforces payments to the managerial class, for the ultimate benefit of the rentier elites. Marazzi argues that the processes of financialization are not simply the exploitations described by Marx, embodied in the analysis of traditional categories of wages, rent, and profit, but rather a new type of capital accumulation adapted to the processes of modern social and cognitive production. Marazzi (2011) contends that chronic financial crises are a fundamental component of contemporary wealth accumulation by the elite, rentier class and not due to a classic lack of stable economic growth. Marazzi shows that individual debt and the management of financial markets are actually techniques "...for governing the transformations of immaterial labour, general intellect, and social cooperation".

Offering a radically new understanding of the current stage of international 
economics, as well as crucial post-Marxist guidance for confronting capitalism in its newest form, Marazzi (2010a) offers in The Violence of Financial Capitalism a model for understanding "the esoteric neo-language of financial capitalism." Marazzi (2011) draws on the class of people with dyslexia as a specific example showing how capitalism controls modes of education and socialisation in modern society, which creates particular self-concepts of stigmatised learners and workers, a fraction of whom, ironically in the present century has been re-identified as a group with special abilities in science and entrepreneurship (Schneps, 2015; Van Viersen et al., 2015; Hall, 2021).

\section{Communication Styles}

A crucial part of neurodiverse identity relates to communication style-the ways in which information from the environment is experienced, processed and communicated in the roles which a capitalist society prescribes for its citizens. This theme is taken up by Christian Fuchs (2020) who develops the ideas of Christian Marazzi and others in developing: "...a critical theory of communication which needs to engage with communication in the context of social struggles and political protests and the quest and vision for alternative communications that are...commons-based or public service." This is a world which underpins capitalist hegemony through creating systems of and beyond communication in which humans as social beings despite the fudge of false news, and music and media created to disable the critical faculty of the proles, are yet capable of developing "a praxis of liberation" (similar to dialectical critical realism, discussed below). In this last instance, according to Fuchs, humans either accept their own enslavement and a media system that upholds this enslavement; or they can struggle for democratic communications in a commons-based society:

In capitalist societies, language is shaped by capital and power and does not stand outside of the processes of commodification, exploitation, and domination. In capitalism, essence and existence of communication diverge: The essence of language and communication is that they are common goods. Their reality in capitalism is that besides communication commons there are cultural and communicational commodities and the communication of ideology. The essence of language and communication as common goods of humanity can only become a full reality in a commons-based society... in such a society, power inequalities can be better addressed, overcome, challenged, and communicated, but do not all automatically vanish. An equal distribution of power is an important goal that can only be achieved politically. (Fuchs, 2020: p. 21)

"Control of the means of communication" has replaced the Marxist dictum of the emancipation of the people through "control of the means of production". This is why Fuchs' analysis is so important since it points to a way in which "we the people" can wrest the flows of mind-numbing "information" from the ruling classes spewed by the electronic media. The "class struggle" is now "the information struggle" which we, the neurodiverse people, must engage in, with a variety 
of possible outcomes (Donati, 2019). This exploration of the changing face and strategies of capitalist ideologies (including the establishment of "false consciousness" ideas in media about neurodiversity and alienation) argues that the original insights of Marx and Engels remain valid in the consideration of group and individual disadvantages by people whom it is convenient (and profitable) to stigmatise. New ethnic groups emerge (to be added to, and intersecting with the neurodiverse strata) whom it is convenient to stigmatise, such as the replacement of Jews by Muslims as targets of hatred and phobia (Adam-Bagley \& Abubaker, 2019).

Aggression (e.g. working class Islamophobia) is a useful way of diverting ("masking") the nature of alienation wrought by capitalist power brokers, and the manipulators of communication and knowledge systems (such as the invention of a set of British values, by the odiously named state agency called Prevent, through which we are enjoined to work hard, hate our faux enemies, and ultimately ourselves-Adam-Bagley \& Al-Refai, 2019). Within working-class strata, neurodiverse groups have traditionally been embedded. Quite recently, the strength of "social capital" (Bourdieu, 1991) exercised by the bourgeoisie has defined some individuals with autism, or dyslexia, as gifted and talented with skills and assets worthy of middle-class status (e.g. Van Viersen et al., 2015). But many in the neurodiverse class remain an underclass, a reserve army of labour, useful for two reasons: they are a stigmatised group through which those with "normal" intellectual and information processing skills and communication styles may acquire pseudo-status as "not being like them"; and the neurodiverse underclass are useful as casually contracted hewers of wood and drawers of water, a convenient and disorganised "reserve army of labour". And within this underclass is group of labelled and self-labelling underclass of mostly men and ethnic minorities who endure the status of chronic offenders (Sawyerr \& Adam-Bagley, 2017b; Christophers, 2019a).

I turn now to examine briefly dialectical critical realism (DCR) as a model for analysing the social world, and advocating change, which DCR theorists described as morphogenesis (Adam-Bagley et al., 2016).

\section{Dialectical Critical Realism: Research and Insights Stemming from the Work of Roy Bhaskar}

Macdonald (2019) offers critical realism as one of a number of sociological approaches to understanding the social class positioning of those with dyslexia, and by implication the neurodiverse strata of society. He is critical however of this and other sociological theories of neurological disadvantage for failing to address the oppressed nature of the neurodiverse class. Despite the managerial class's trawling the neurodiverse sector for "talented" neurodiverse individuals, they remain, according to social class analyses (Macdonald, 2019; Macdonald \& Deacon, 2019), society's most degraded sector. The critical realist approach offered here is an "intellectual" social action approach to the exploitation and dis- 
advantage of children and learners in general (based on "Marxist humanism"-Banfield, 2015), but it does offer some ways for organising social change which unmasks the degrees of alienation imposed on neurodiverse individuals (Bhaskar, 2002a, 2002b, 2008; Bhaskar \& Danemark, 2006; Alderson, 2013, 2015).

Critical Realism has been attractive to social researchers, and theorists who are committed to a firm ideological basis for viewing human action (e.g. Marxists, Muslims, Catholics) in asserting that structures within society are real and although their nature and influence may be debated, their being or ontology (e.g. class exploitation, alienation, the nature of spiritual being) is not in doubt. We have followed Alderson $(2013,2015)$ in constructing a model of social action in which minority children in Britain are able to conceptualise, address and overcome the sources of their alienation (Sawyerr \& Adam-Bagley, 2017a). While our work has addressed mainly the identity development of African Caribbean children and adolescents in Britain, the model can certainly be extended to neurodiversity in general (Sawyerr \& Adam-Bagley, 2017b). Another example of employing the DCR model is in addressing the exploitation of nurses during the COVID crisis (Adam-Bagley et al., 2021).

The important application of DCR in unmasking alienation is through what Margaret Archer $(1995,2000,2003,2021)$ describes as morphogesis, a dialogue aimed at deconstructing the nature of alienation (e.g. as neurodiverse persons), through a process described as dialectical critical realist dialogue in which we, the stigmatised and oppressed, create communication streams which struggle to unmask our alienation. Archer's student, Sally Tomlinson (2012a, 2012b, 2014, 2015, 2017) chronicles the struggles surrounding the SEND SEND (Special Educational Needs) industry in British education, and exposes how some 15 percent of children are shunted into a permanent underclass through "the manufacture of inability", a group for whom there are relatively few advocates (Sawyerr \& Adam-Bagley, 2017b).

My own neurodiverse condition is epilepsy, the subject of earlier research (Adam-Bagley, 1972a, 1972b). Epilepsy is a curiously neglected condition in the literature on the stigmatisation of "the neurologically odd" (de Boer, 2010), perhaps because of a latent horror on the part of many people at the sudden outburst of "motor violence" which the person with epilepsy seeks so desperately to conceal. All of this is a far cry from the chronic challenges of "dyslexia" unless one conceives of neurodiversity as a progressive and inclusive social class, in which we join with our brothers and sisters in communication and dialogue, in order to unmask our shared alienation (Porpora, 2013).

\section{Conclusion}

Dyslexia is a condition which often intersects with other disadvantaged statuses, in defining a group who are part of a community who are labelled the neurodiverse, a disadvantaged but emerging group whose "class consciousness" defines 
them as a "class within a class", to employ the terminology of a Marxist analysis. From the point of view of Marxist humanism (Banfield, 2015) each individual member of this neurodiverse strata is a unique individual, whom society at large should reward with the basic income due to all members of society, with each neurodiverse citizen offering support with dialogue to every other member of society in the morphogenetic dialogue, "according to their ability".

We champion the work of Janine Booth (Booth, 2016, 2018, 2021) and others such as James Richards (Richards, 2020; Richards \& Sang, 2016), on trade union support for the neurodiverse; and Nick Walker's Marxist programme of support for this class within a class, (Walker, 2014-2021) who are well described and advocated for by Silberman (2017). We frame these conceptualisations of "disability" within a Marxian analysis of capitalist exploitation and social class. Marx's models of how capital acquires and uses power through "surplus value" remain highly relevant today, in a new era of neoliberalism capitalist enterprise whose rentier class operates internationally, increasing profit through the exploited efforts of managers, technicians, skilled workers, and an unskilled reserve army of labour. It is into this underclass that many neurodiverse people are relegated, to be used for profit whenever capital requires their casual labour.

We offer the insights of the dialectical critical realist model as one way of "unmasking" this alienation through the consciousness-raising dialogue of oppressed people. Electronic modes of knowledge generation and communication are expertly used by capital in order to stultify the consciousness of the masses: yet these communication media (following Christian Fuchs) may also be the modes by which the neurodiverse underclass communicate and expose the nature of their exploitation.

\section{Conflicts of Interest}

The author declares no conflicts of interest regarding the publication of this paper.

\section{References}

Adam-Bagley, C. (1972a). The Social Psychology of the Child with Epilepsy. Routledge.

Adam-Bagley, C. (1972b). Social Prejudice and the Adjustment of People with Epilepsy. Epilepsia, 13, 33-45. https://doi.org/10.1111/j.1528-1157.1972.tb04547.x

Adam-Bagley, C., \& Abubaker, M. (2019). Muslim Women (and Men) and Youth Seeking Justice: English and Dutch Case Studies of Prejudice, Racism, Discrimination and Achievement. In C. Adam-Bagley, \& M. Abubaker (Eds.), Muslim Women Seeking Power, Muslim Youth Seeking Justice (pp. 162-181). Cambridge Scholars Publishing.

Adam-Bagley, C., \& Al-Refai, N. (2019). Muslim Youth in Britain: Becoming Good Citizens in the Age of Islamophobia. In C. Adam-Bagley, \& M. Abubaker (Eds.), Muslim Women Seeking Power, Muslim Youth Seeking Justice (pp. 120-161). Cambridge Scholars Publishing.

Adam-Bagley, C., Sawyerr, A., \& Abubaker, M. (2016). Dialectic Critical Realism: Grounded Values and Reflexivity in Social Science Research. Advances in Applied Sociology, 6, 400-419. https://doi.org/10.4236/aasoci.2016.612030 
Adam-Bagley, C., Sawyerr, A., Abubaker, M., \& Shahnaz, A. (2021). Resilient Nurses Coping with Covid Care: A Longitudinal Study of Psychology, Values, Resilience, Stress and Burnout. Journal of Human Resource \& Leadership, 5, 88-105.

Adler, M. (2019). Class. In M. E. Blum (Ed.), The Marxist Conception of the State (pp. 60-82). Brill.

Alderson, P. (2013). Childhoods Real and Imagined: An Introduction to Critical Realism and Childhood Studies. Routledge. https://doi.org/10.4324/9780203805350

Alderson, P. (2015). The Politics of Childhoods Real and Imagined: Practical Application of Critical Realism and Childhood Studies. Routledge. https://doi.org/10.4324/9781315669380

Archer, M. S. (1995). Realist Social Theory: The Morphogenetic Approach. Cambridge University Press. https://doi.org/10.1017/CBO9780511557675

Archer, M. S. (2000). Being Human: The Problematic Agency. Cambridge University Press. https://doi.org/10.1017/CBO9780511488733

Archer, M. S. (2003). Structure, Agency and the Internal Conversation. Cambridge University Press. https://doi.org/10.1017/CBO9781139087315

Archer, M. S. (2021). Sapience and Sentience: A Reply to Porpora. In M. S. Archer, \& A. M. Maccarini (Eds.), What Is Essential to Being Human (pp. 40-55). Routledge. https://doi.org/10.4324/9780429351563-3

Banfield, G. (2015). Critical Realism for Marxist Sociology of Education. Routledge. https://doi.org/10.4324/9781315685212

Bannerji, H. (2005). Building from Marx: Reflections on Class and Race. Social Justice, 32, 144-160.

Bhaskar, R. A. (2002a). From Science to Emancipation: Alienation and Enlightenment. Routledge.

Bhaskar, R. A. (2002b). Meta-Reality. Sage.

Bhaskar, R. A. (2008). Dialectic: The Pulse of Freedom. Routledge. https://doi.org/10.4324/9780203892633

Bhaskar, R. A., \& Danermark, B. (2006). Metatheory, Interdisciplinarity and Disability Research: A Critical Realist Approach. Scandinavian Journal of Disability Research, 8, 278-297.

Booth, J. (2016). Autism Equality in the Workplace. Jessica Kingsley Publishers.

Booth, J. (2018). Neurodiversity under Capitalism and Socialism. https://www.janinebooth.com

Booth, J. (2021). Autism and Other Neurodivergent Conditions. https://www.janinebooth.com

Bourdieu, P. (1991). Language \& Symbolic Power. Polity Press.

Christophers, B. (2018). The New Enclosure: The Appropriation of Public Land in Neoliberal Britain. Verso.

Christophers, B. (2019a). The Rentierization of the United Kingdom Economy. Environment and Planning A: Economy and Space, 50, 1-33. https://doi.org/10.1177/0308518X19873007

Christophers, B. (2019b). Rentier Capitalism: The UK Case. Cambridge University, Bennett Institute of Public Policy.

Christophers, B. (2020). Rentier Capitalism: Who Owns the Economy, and Who Pays for It? Verso.

Christophers, B. (2021). Class, Assets and Work in Rentier Capitalism. Historical Materi- 
alism, 1, 1-26.

Collins, C. (2021). Silver Spoon Oligarchs: How America's 50 Largest Inherited-Wealth Dynasties Accelerate Inequality. Institute for Policy Studies.

de Boer, H. M. (2010). Epilepsy Stigma: Moving from a Global Problem to Global Solutions. Seizure, 19, 630-636. https://doi.org/10.1016/j.seizure.2010.10.017

Donati, P. (2019). The Digital Matrix and the Hybridisation of Society. In I. Al-Amoudi, \& E. Lazega (Eds.), Post-Human Institutions and Organizations (pp. 67-92). Routledge. https://doi.org/10.4324/9781351233477-5

Drucker, J., \& Hakins, D. (2021). Private Inequity. New York Times Online.

Dünhaupt, P. (2012). Financialization and the Rentier Income Share-Evidence from the USA and Germany. International Review of Applied Economics, 26, 465-487. https://doi.org/10.1080/02692171.2011.595705

Ford, J. (2020). Private Equity Fees Have Become a Rentier's Bonanza. Financial Times Online.

Fuchs, C. (2020). Communication and Capitalism: A Critical Theory. University of Westminster Press. https://doi.org/10.2307/j.ctv12fw7t5

Hall, R. (2021). People with Dyslexia Have Skills that We Need, Says GCHQ: UK Surveillance Agency Says It Has Long Valued Neuro-Diverse Analysts-Including Alan Turing. The Guardian Online.

Hamsa, A. (2018). Marx’s Dyslexia. Los Angeles Review of Books.

Harvey, D. (2017) Marx, Capital, and the Madness of Economic Reason. Oxford University Press.

Holpuch, A. (2021). Wealth Secret of the Super-Rich Revealed: The 10 Richest Dynasties Grew Their Net Worth by $\$ 136$ bn during the Pandemic. The Guardian Online.

Hurst, C. E. (2007). Social Inequality: Forms, Causes, and Consequences. Allyn and Bacon.

Macdonald, S. J. (2019). From 'Disordered' to 'Diverse': Defining Six Sociological Frameworks Employed in the Study of Dyslexia in the UK. Insights into Learning Disabilities, 16, 1-22.

Macdonald, S. J., \& Deacon, L. (2019). Twice upon a Time: Examining the Effect Socio-Economic Status Has on the Experience of Dyslexia in the United Kingdom. Dyslexia, 25, 3-19. https://doi.org/10.1002/dys.1606

Marazzi, C. (2010a). The Violence of Financial Capitalism. MIT Press.

Marazzi, C. (2010b). Neoliberalism Is Destroying Europe. The Guardian Online.

Marazzi, C. (2011). Dyslexia and the Economy. Angelaki: Journal for the Theoretical Humanities, 16, 19-32. https://doi.org/10.1080/0969725X.2011.621216

Milner, A. (2019). Class and Class Consciousness in Marxist Theory. International Critical Thought, 9, 161-176. https://doi.org/10.1080/21598282.2019.1613165

Porpora, D. V. (2013). Morphogenesis and Social Change. In M. Archer (Ed.), Social Morphogenesis (pp. 25-37). Springer. https://doi.org/10.1007/978-94-007-6128-5_2

Richards, J. (2020). Trade Unions and Dyslexia Support. Paper Given to Virtual International Dyslexia Conference.

Richards, J., \& Sang, K. (2016). Trade Unions as Employment Facilitators for Disabled Employees. The International Journal of Human Resource Management, 27, 1642-1661. https://doi.org/10.1080/09585192.2015.1126334

Sawyerr, A. A. A., \& Adam-Bagley, C. (2017a). Equality and Ethnic Identities: Studies of 
Self-Concept, Child Abuse and Education in a Changing English Culture. Brill, Sense Education Series. https://doi.org/10.1007/978-94-6351-080-6

Sawyerr, A. A. A., \& Adam-Bagley, C. (2017b). Excluded Youth in Britain: Historical Review of Research on Inequality, Education, Health and Family Support for Excluded Youth 1998-2008. In Equality and Ethnic Identities (pp. 265-374). Brill, Sense Education Series.

Schneps, M. (2015). The Advantages of Dyslexia. Scientific American Mind, 26, 24-25. https://doi.org/10.1038/scientificamericanmind0115-24

Shaxson, N. (2018). The Finance Curse: How Global Finance is Making Us All Poorer. Penguin Random House LLC.

Silberman, S. (2017). Neurotribes: The Legacy of Autism and the Future of Neurodiversity. Penguin Random House LLC.

Standing, G. (2010). Work after Globalization: Building Occupational Citizenship. Edward Elgar Publishing.

Standing, G. (2012). The Precariat: From Denizens to Citizens? Polity, 44, 588-608. https://doi.org/10.1057/pol.2012.15

Standing, G. (2014). A Precariat Charter: From Denizens to Citizens. Bloomsbury Publications. https://doi.org/10.5040/9781472510631

Standing, G. (2021). The Corruption of Capitalism: Why Rentiers Thrive and Work Does Not Pay (3rd ed.). Biteback Publishing.

Tomlinson, S. (2012a). The Irresistible Rise of the SEN Industry. Oxford Review of Education, 38, 267-286. https://doi.org/10.1080/03054985.2012.692055

Tomlinson, S. (2012b). A Sociology of Special Education. Routledge. https://doi.org/10.4324/9780203126592

Tomlinson, S. (2014). The Politics of Race, Class and Special Education: The Selected Works of Sally Tomlinson. Routledge. https://doi.org/10.4324/9781315794785

Tomlinson, S. (2015). Is a Sociology of Special and Inclusive Education Possible? Educational Review, 67, 273-281. https://doi.org/10.1080/00131911.2015.1021764

Tomlinson, S. (2017). A Sociology of Special and Inclusive Education: Exploring the Manufacture of Inability. Taylor \& Francis.

Van Viersen, S., De Bree, E., Kroesbergen, E., Slot, E., \& De Jong, P. (2015). Risk and Protective Factors in Gifted Children with Dyslexia. Annals of Dyslexia, 65, 178-198. https://doi.org/10.1007/s11881-015-0106-y

Walker, N. (2014-2021). Toward a Neurocosmopolitan Society. Web-Based Essays on Autism, Neuroqueering and Self-Liberation. https://neuroqueer.com

Zizek, S., Ruda, F., \& Hamza, A. (2018). Reading Marx. John Wiley \& Sons. 


\section{Appendix}

Table 1. The rentier class: Types and examples from the UK (from Christophers, 2019a, 2019b, 2020).

\begin{tabular}{lll}
\hline Type of Rentier Activity & Rentier Activity Examples & $\begin{array}{l}\text { Examples of International Rentier Companies with } \\
\text { UK income }\end{array}$ \\
\hline Financial & $\begin{array}{l}\text { Income from dividends \& capital gains } \\
\text { Pand }\end{array}$ & $\begin{array}{l}\text { Barclays; HSBC; Lloyds } \\
\text { state-owned enterprises }\end{array}$ \\
Natural Resources & Mineral rights, mining, oil \& gas ownership & $\begin{array}{l}\text { British Land Corporation; Land Securities } \\
\text { (Landsec); GP Strategies Co. }\end{array}$ \\
Knowledge Control & Ownership of patents \& trademarks & Glaxo Smith Kline; Diageo \\
Communications \& Media & Ownership of media outlets \& licences & Vodafone; CK Hutchison; Google \\
Digital Platforms & Creative media, advertising & BT; Telefonica (Virgin/O2); Cadent; Arqiva \\
Natural Monopolies & Privatisation of formerly state-owned enterprises BT; Cadent Gas; Arqiva \\
Service Contractors & Transport Systems; Power \& Water Utilities & Capita; Serco Transport; ISG Technology
\end{tabular}

Note: Rise of Rentier Class accelerated since UK's privatisation movement following government espousal of neoliberal privatisation policies in 1979, and their perpetuation by subsequent Conservative, Labour and Coalition governments. In each "example" up to 50 companies can be listed with rentier capital reserves of more than $\$ 1$ trillion.

Table 2. Proportions of national wealth held by different UK class groups, including "The Neurodiverse".

\begin{tabular}{lll}
\hline Name of Class & $\%$ of "National” Wealth Held & $\%$ of Population (e.g. UK) \\
\hline The Rentiers & $80 \%$ & $2 \%$ \\
Rentier Service Group & $6 \%$ & $5 \%$ \\
(Some MPs, Local Company Directors \& Board Members) & $4 \%$ & $7 \%$ \\
Managerial Lackeys, Overseers, Judges, Senior Civil Servants & $3 \%$ & $12 \%$ \\
Middle Managers/Professionals & $2 \%$ & $22 \%$ \\
Lower Managers \& Supervisors & $2 \%$ & $12 \%$ \\
Artisans \& crafts people & $2 \%$ & $6 \%$ \\
Higher Neurodiverse Specialists & $1 \%$ & $4 \%$ \\
Middle Neurodiverse Specialists & $0 \%$ & $10 \%$ \\
Lower Neurodiverse People & $0 \%$ & $10 \%$ \\
Neurodiverse Underclass & $0 \%$ & $10 \%$ \\
Lumpen Proletariat (Stigmatised \& Criminalised Underclass) & & $6 \%$ \\
\hline
\end{tabular}

Note: Since the Rentier Class controls the nature of, and access to much public and academic information, these are estimates only (sources Marazzi, 2011; Sawyerr \& Adam-Bagley, 2017b; Standing, 2010, 2021; Dünhaupt, 2012; Harvey, 2017; Christophers, 2018, 2019a, 2019b, 2020, 2021; Ford, 2020; Holpuch, 2021). 